\title{
Effect of Azadirachta excelsa (Jack) Leaf Extracts on the Reproductive Organs and Fertility of Male albino Mice (Mus musculus)
}

\author{
Waad S. Shaher \\ Department of Biology \\ College of Science \\ Mosul University
}

(Received 3 / 3/ 2009 ; Accepted 15 / 6 / 2009)

\begin{abstract}
This study was conducted to investigate the effect of oral dose (250mg/kg body weight/day, for 21 days) of each aqueous and alcohol leaf extract of Azadirachta excelsa on histological structure of the testis and fertility of male albino mice Mus musculus. Histological structure of the testis of both treated groups showed affected seminiferous tubules indicating mixing of the germ cell types in stages of spermatogenesis, atrophy of the spermatogenic elements, increases in number of Leydig cells, occurrence of giant cells and decrease $s$ or absence of the spermatozoa in the lumen of the seminiferous tubules as compared with control group. The other alternations of both treated groups were decrease in number of the spermatozoa in the Ductus epididymidis. The fertility index of the treated groups was reduced, this result which proves the fertility was observed in untreated females after mated with treated males.
\end{abstract}

Keyword: Azadirachta excelsa, Leaf extract, Testis, Histopathology, Spermatozoa, Fertility.

\section{تأثير طستخلصك الورق Azadirachta excelsa عل الاعضاء التكاثربة وخصومة نكور}

\section{Mus Musculus}

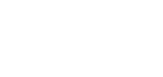

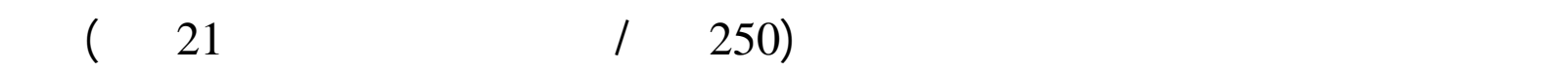

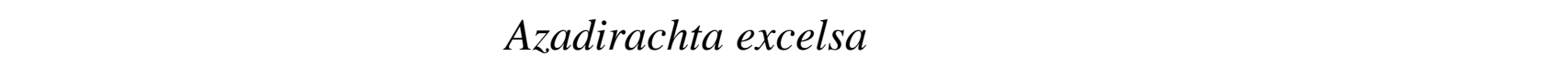

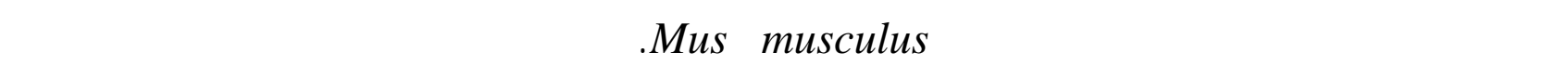

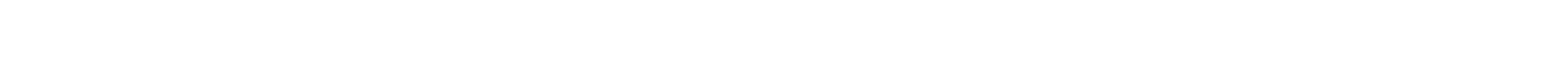

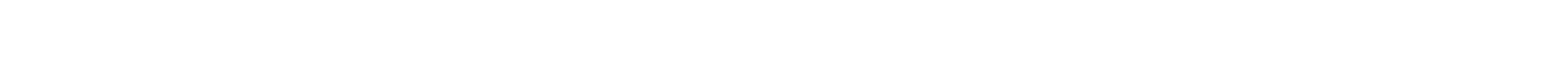


Waad S. Shaher

غيلب الطف في تجويف النبيبت المنوية مقارنة بمجموعة اللسيطرة. ومن التغييرات الاخرى لكلا المجلميع

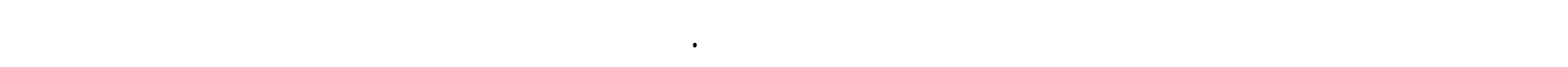

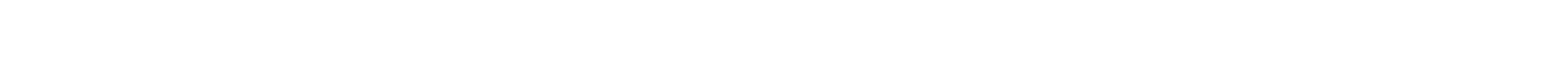
النكور المعلملة.

\section{INTRODUCTION}

Azadirachta excelsa belongs to family meliaceae, which comprises of 50-52 genera with about 550 species, it looks like a very tall Neem tree (A.indica) and it may reaches a height of 40-50 meters, it is known by different common names, one of these Marrango in Philippine (Schumutterer and Doll, 1993; Norani, 1997). The highest yields of azadirachtin of A.excelsa leaf extracts were not restricted to species provenance but they came from single tree of different origin (Nor Aini and Seong, 2006).

Meliaceae is a plant family whose tree has numerous useful characteristics such as medical and pesticidal properties. One candidate of this family, Azadirachta indica, possesses these characteristics and has been used widely in ayurvedic medicine in India (Randhawa and Parmar, 1993). Also A.excelsa tree with various parts have been used as traditional medicine, (antiseptic, anti-inflammatory, antimicrobial agent) antifeedant, insecticidal (Chungponse and Buranatham, 1991; Lean et al., 2003; Akhatar et al., 2008). Macedo et al., 2007, observed that the increasing doses of A.indica leaf extract did not improve the control of endoparasites naturally infected.

Numerous studies on experimental animals have been shown that A.indica seed extracts have transient and reversible antifertility and abortive effects (Bardhan et al., 1991; Mukherjee et al., 1999). Antifertility effects of neem oil were observed by Shakati et al., 1990, in female rats which remained infertile for variable periods.

There are a few studies about the effects of A.excelsa on mammals, one of these studies referred that in concentrations up to 200ppm, the leaf extracts of A.excelsa was much more effective than of Melia azadarach, the extract of A.indica was in the third place (Doll and Schumutterer, 1993; Schumutterer and Doll, 1993; Hein, 1994).

The objective of this study was to determine the effect of A.excelsa leaf extracts on reproductive organs and fertility in male mice.

\section{MATERIAL AND METHODS}

\section{Plants:}

Green leaves of Azadirachta excelsa J. were collected from the gardens of university of Mosul during August 2005. Leaves washed in running tap water and dried to powder using a mechanical grinder.

\section{Preparation of extracts:}

The method of plant extraction was modified from (Choochote et al., 1999). 50grams of the powdered leaves was macerated with $200 \mathrm{ml}$ of $75 \%$ ethanol alcoholic solution and left to stand at room temperature for 24 hours. The mixture was filtered through a Whatman 
no.1 filter paper by suction and the filterate was evaporated under vaccum at $40^{\circ} \mathrm{C}$ until completely dried and kept at constant $4^{\circ} \mathrm{C}$ until needed for experiments. For aqueous extract $50 \mathrm{~g}$ of the powdered leaves was macerated with $200 \mathrm{ml}$ of distilled water for 24 hours and the mixture was filtered.

\section{Animals:}

In this study 15 males, 18 females of albino mice were used. They were 3 months old, weighting (22-28g). The males were divided into 3 groups each one contains 5 males isolated in plastic cages. The first group was given $0.2 \mathrm{ml} \mathrm{d.w}$. and regarded a control group. The second group was forced feeding orally dose of aqueous extract $(250 \mathrm{mg} / \mathrm{kg}$ ) of body weight daily for 3 weeks. The third group with alcohol extract $(250 \mathrm{mg} / \mathrm{kg})$ of b.w. daily for the same period. All groups were exposed to a constant laboratory condition, temperature was about $25^{\circ} \mathrm{C}$ and light/dark cycle of $12: 12 \mathrm{~h}$. and fed with standard commercial diet and given water.

Three of treated males of each group were mated with six untreated nonpregnant females to prove fertility (one male with two females). After one week the males were removed from the cages. The pregnant females were observed daily after 3 weeks of gestation and the number of offspring from each female was recorded and weighted as soon as possible after birth. The other two males of each group were anesthetized with chloroform and dissected, testis were carefully isolated for study of histopathological changes. After routine preparations the organs were embedded in paraffin and sections were cut $6 \mu$ and stained with a double stain haematoxylin-eosin.

\section{RESULTS}

The effects of oral administration (250mg/kg body weight/day for 21 days) of aqueous and alcohol leaf extracts of Azadirachta excelsa on male reproductive organs and fertility of male albino mice were investigated. The section of the testis in control group indicating normal spermatogenesis (Fig. 1), the seminiferous tubules were lined with three or four regular layers of seprmatogenic cells at different stages of maturation, and mature spermatozoa were observed. But in the treated mice, the testes showed affected seminiferous tubules, indicating mixing of the germ cell types in the stages of spermatogenesis, mass atrophy of spermatogenic elements, degenerated appearance of germ cells and decreased or absence of the spermatozoa in the lumen of seminiferous tubules (Fig. 2, 3).

The affected seminiferous tubules showed loosening some of the germinal epithelium and separating the spermatogenic cells from the germinal layer (Fig. 2), and increase in number of Leydig cells (Fig. 4, 5).

In both treated groups, seminiferous tubules showed congestion of the blood vessels, and occurrence of giant cells (Fig. 6, 7). A general reduction in diameters of some seminiferous tubules of alcohol treated group and foamy substance has been observed as well as a reduction of interstitial tissues. (Fig. 8).

The treated groups also showed a general decrease in the number of spermatozoa in the lumen of the ductus epididymidis as compared with control group (Fig. 9, 10, 11). Also alcohol treated group showed a reduction in diameters of the ductus epididymidis (Fig. 11). 

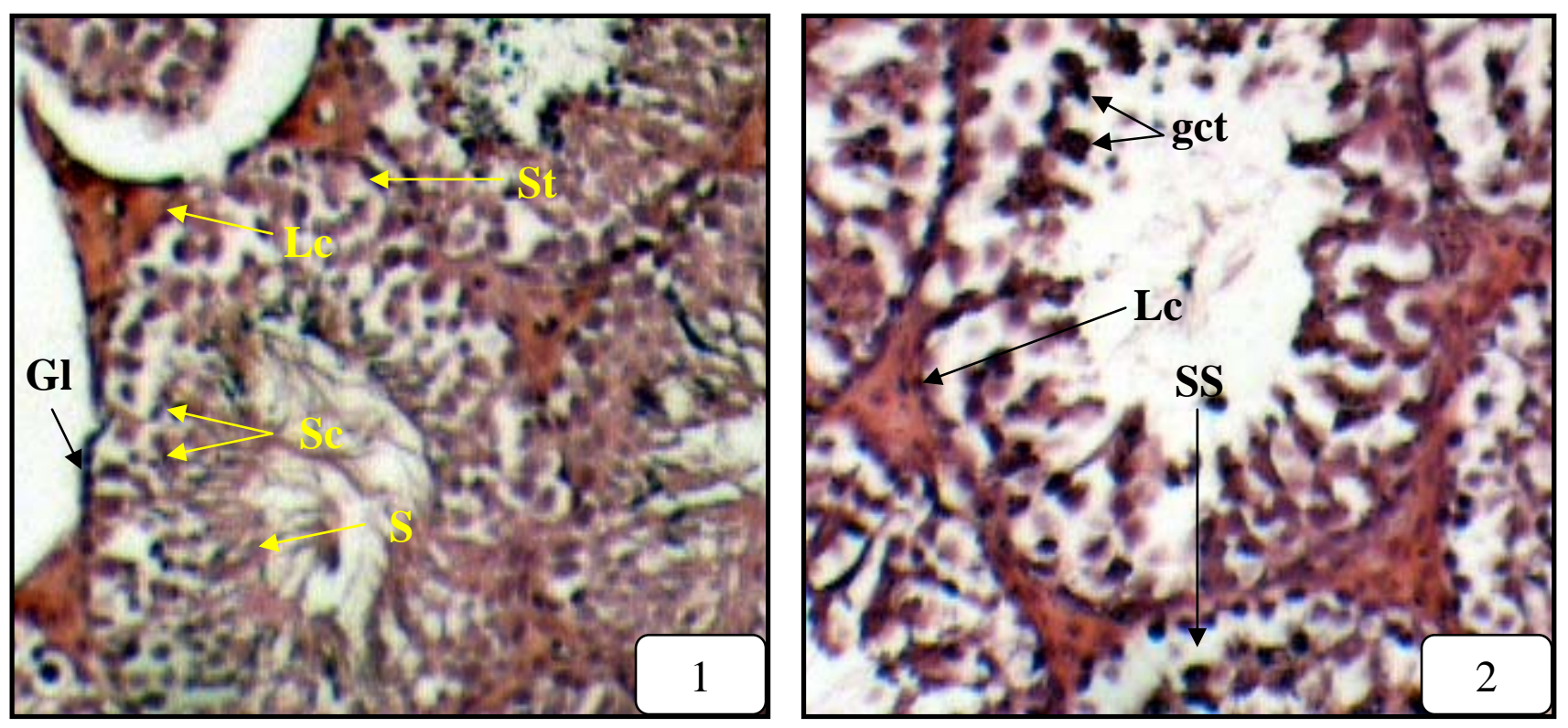

Fig.1: Section of the testis of the control male mice, Mus musculus showing Seminiferous tubules-St, with (3-4) Layers of spermatogenic cells-Sc, spermatozoa-S, germinal layer-Gl, Leydig cells-Lc. H.and E. X160.

Fig.2: Section of the testis of the male mice treated with aqueous leaf extract of A.excelsa showing mixing of germ cell types-gct, absence of spermatozoa, occurrence of separating space-SS, Leydig cells-Lc, H.and E. X160.
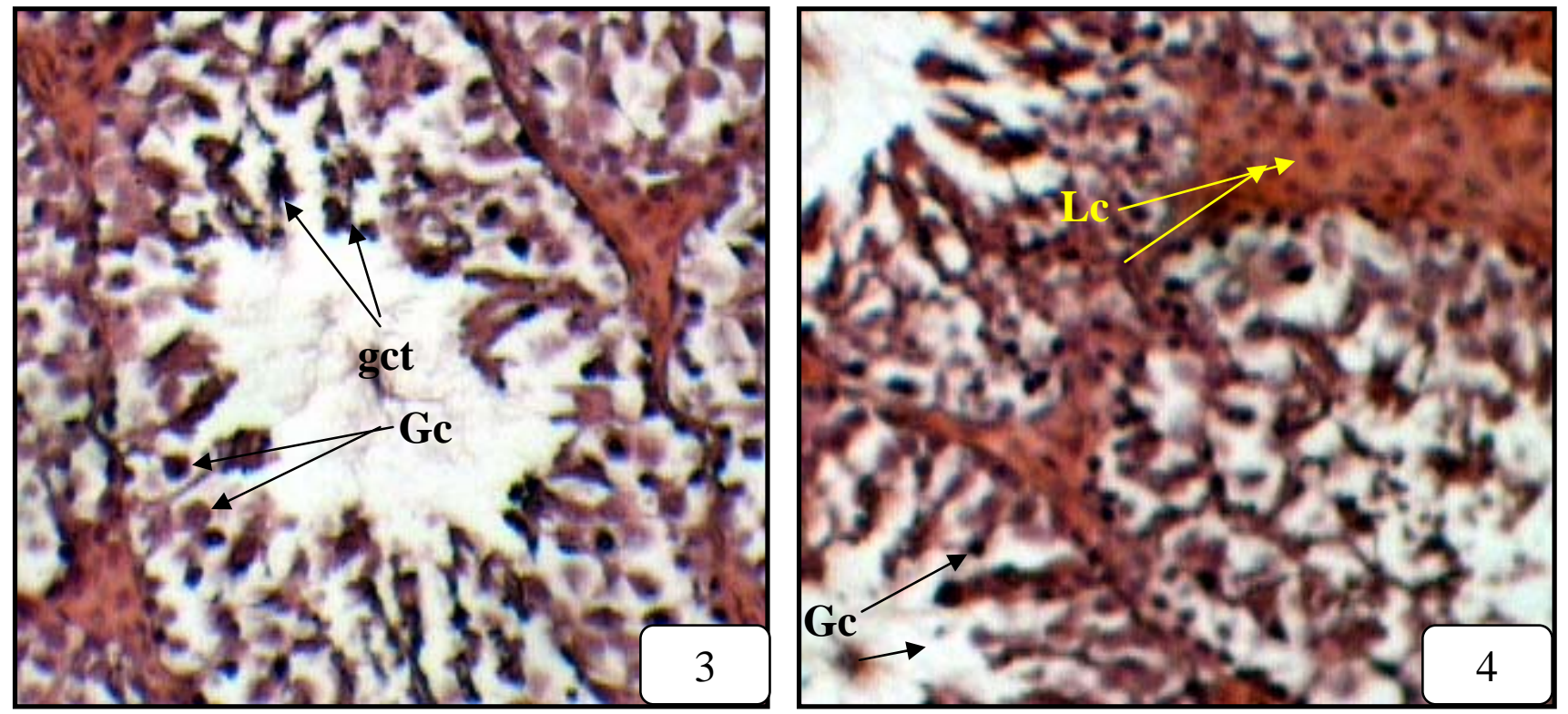

Fig.3: Section of the testis of male mice, treated with alcohol leaf extract of A.excelsa showing mixing of germ cell type-gct, absence of spermatozoa in seminiferous tubules. Occurrence giant cells- Gc. H.and E. X160.

Fig.4: Section of the testis of the male mice treated with aqueous leaf extract of A.excelsa showing increasing of Leydig cells -Lc, occurrence of giant cells-Gc. H. and E. X160. 

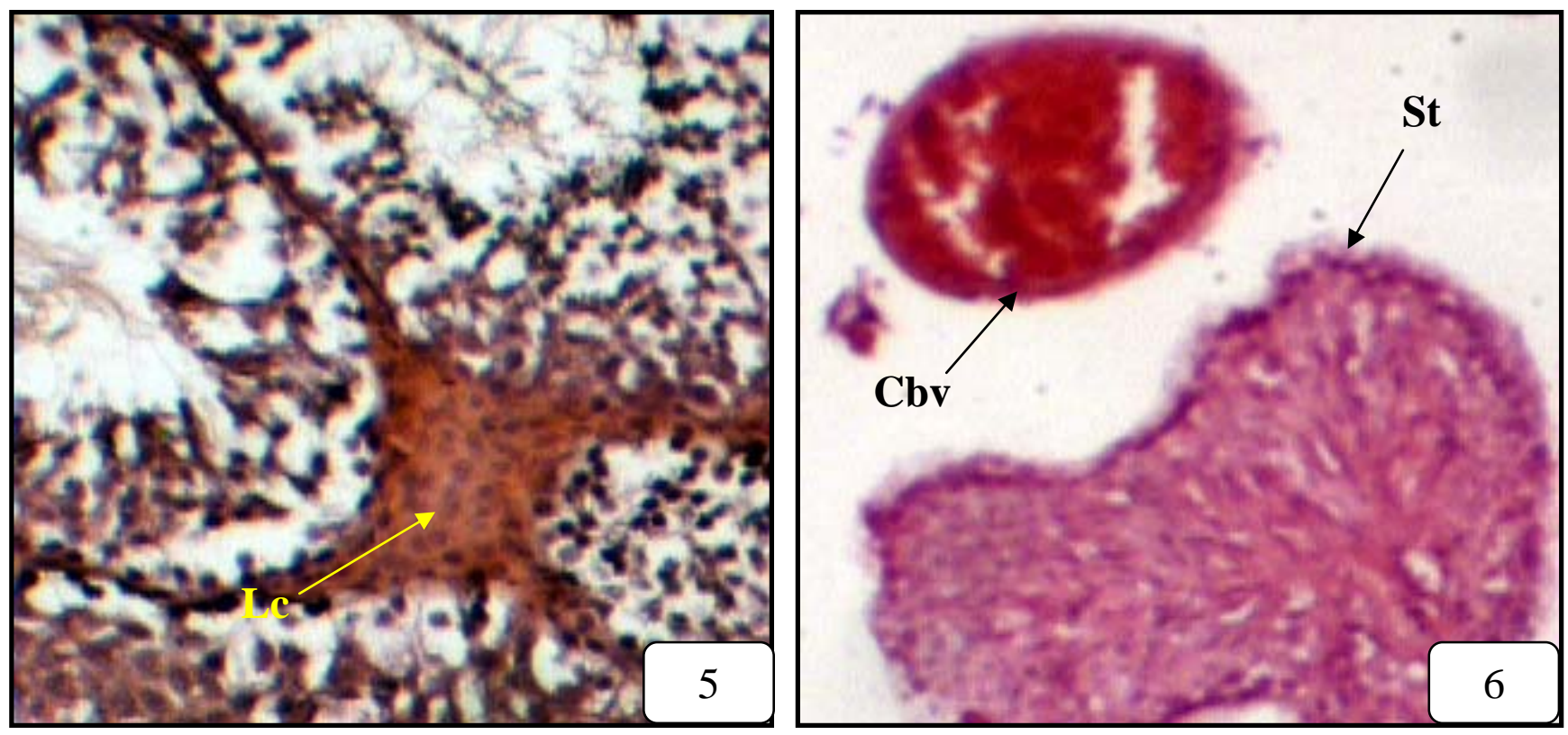

Fig.5: Section of the testis of male mice, treated with alcohol leaf extract showing increasing Leydig cells-Lc. H.and E. X160.

Fig.6: Section of the testis of the male mice treated with aqueous leaf extract showing congestion of blood vessel-Cbv, Seminiferous tubule-St. H.and E. X640.
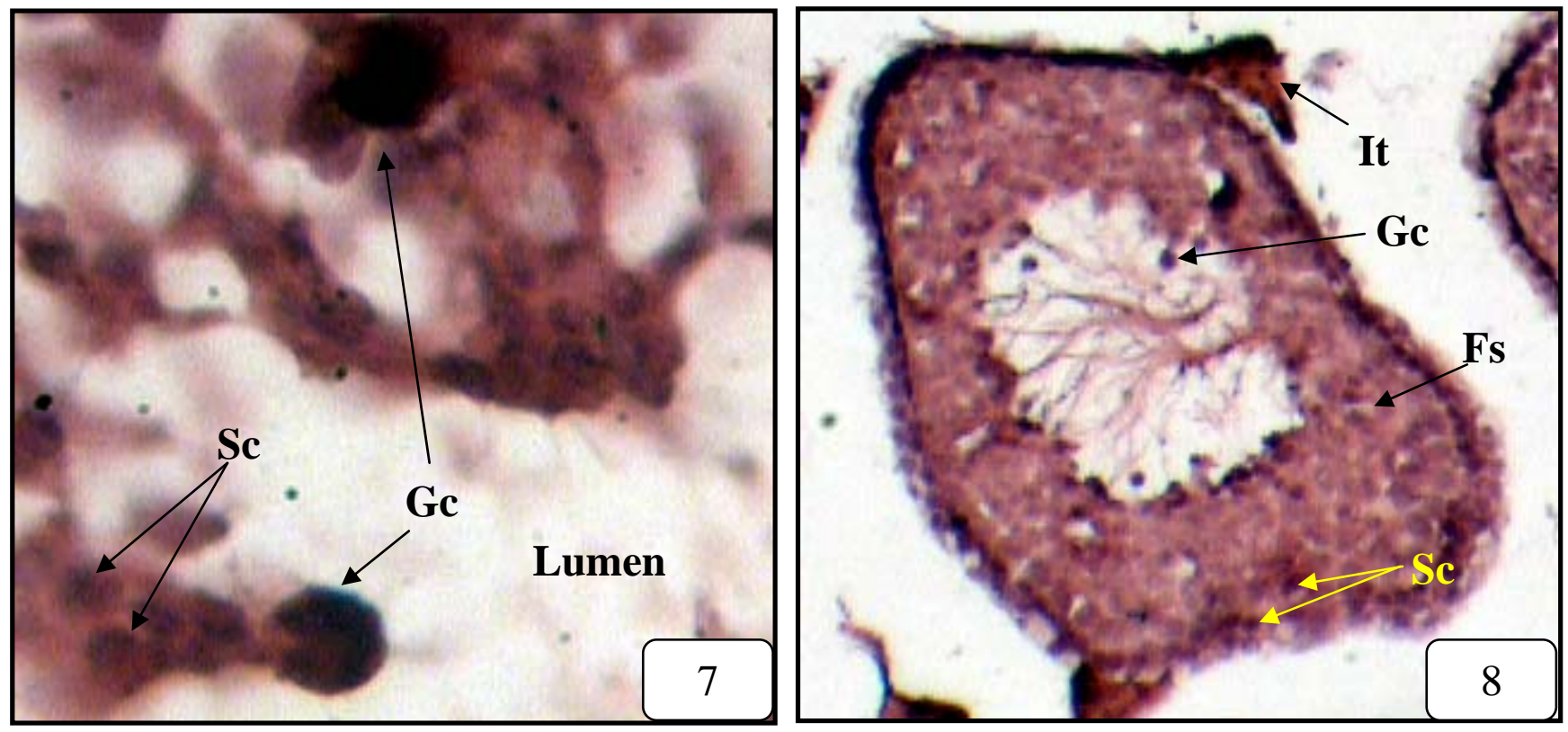

Fig.7: Section of the testis of male mice, treated with aqueous leaf extract showing occurrence of giant cells-Gc, spermatogenic cells-Sc. H.and E. X640.

Fig.8: Section of the testis of the male mice treated with alcohol leaf extract showing a reduction in diameters of seminiferous tubule mass atrophy of spermatogenic elements and foamy substance-Fs, interstitial tissues-It. H.and E. X160. 

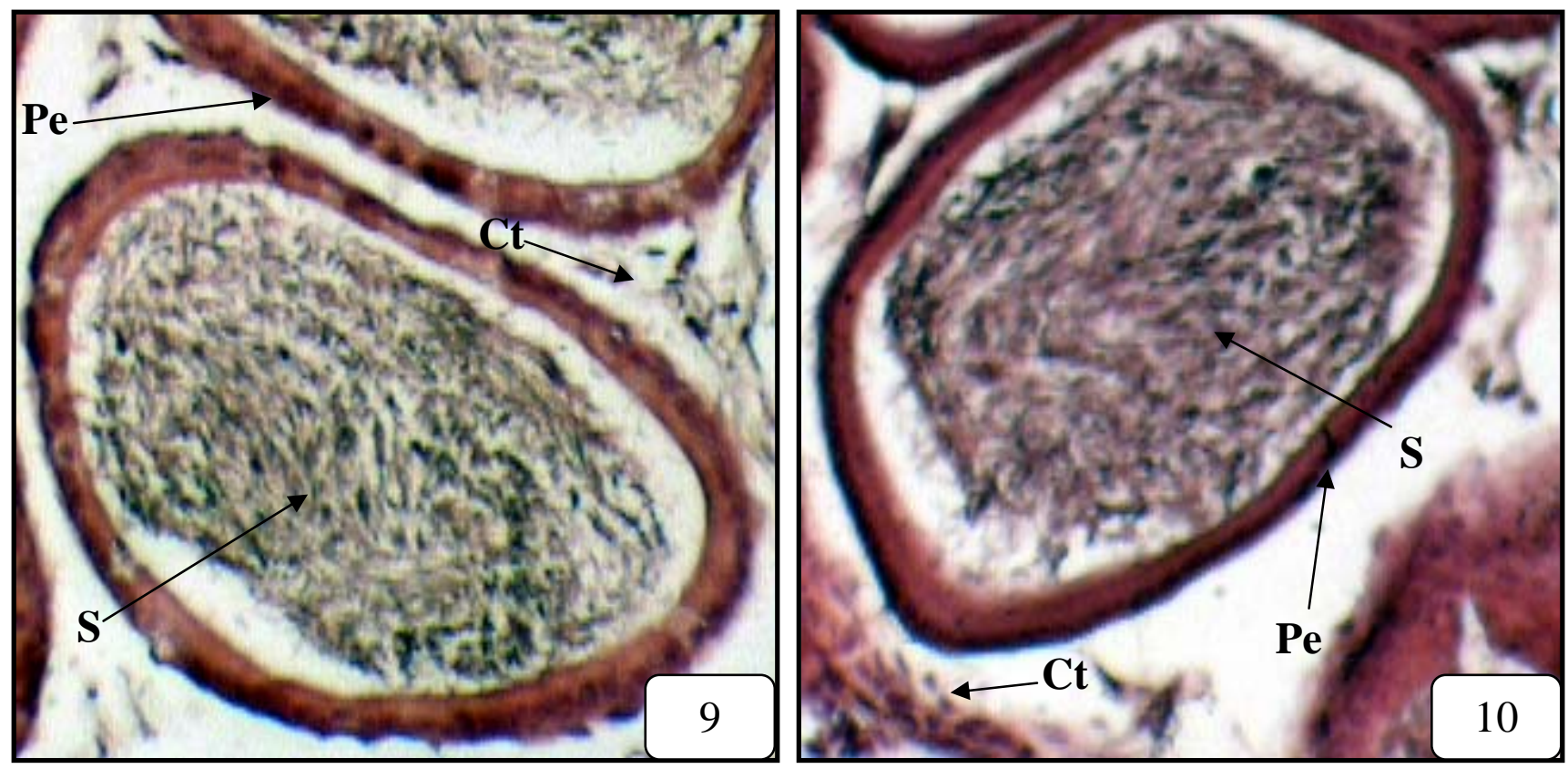

Fig.9: Section of the ductus epididymidis of control male mice, showing pseudostratified epithelium-Pe, lining the duct. Large mass of the sperms-S, in the lumen of the ductus connective tissues-Ct. H.and E. X160.

Fig.10: Section of the ductus epididymidis of the a queous treated group showing a less mass of sperms-S in the lumen of the ductus as compared with control group. H.and E. X160.

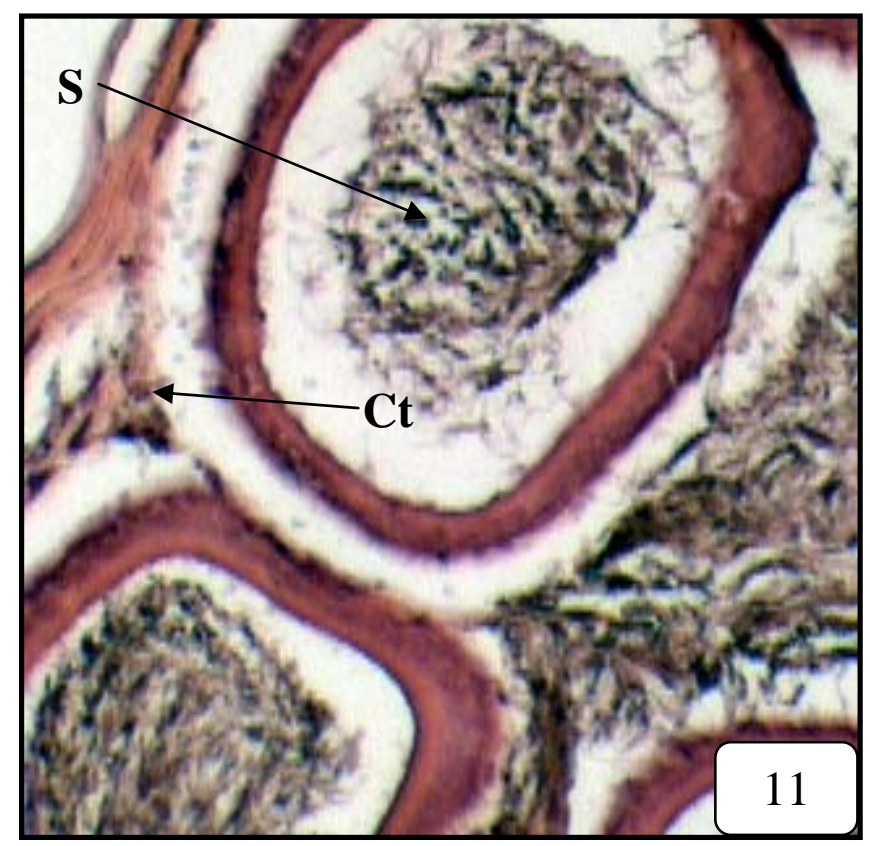

Fig.11: Section of the ductus epididymidis of the alcohol treated group showing a least mass of the sperms-S, in the lumen of the ductus as compared with control group, connective tissue-Ct. H.and E. X160. 
The results showed that the mean number of newborns was decreased in the normal females which mated with treated males and the fertility index was reduced from $100 \%$ in control group to $83.33 \%, 66.66 \%$ in aqueous and alcohol treated groups respectively (Table 1).

Table 1: Effect of Azadirachta excelsa leaf extracts on mean number of newborn and fertility index (six females for group).

\begin{tabular}{|c|c|c|c|c|}
\hline Group & $\begin{array}{c}\text { Dose } \\
\mathbf{m g} / \mathbf{k g}\end{array}$ & $\begin{array}{c}\text { No. of females } \\
\text { pregnant }\end{array}$ & $\begin{array}{c}\text { Mean No. of } \\
\text { newborn } \pm \text { SE }\end{array}$ & $\begin{array}{c}\text { Fertility } \\
\text { \% }\end{array}$ \\
\hline Control & - & 6 & $8.0 \pm 0.32$ & 100 \\
\hline $\begin{array}{c}\text { Aqueous A.excelsa } \\
\text { extract }\end{array}$ & 250 & 5 & $5.0 \pm 2.61$ & 83.33 \\
\hline $\begin{array}{c}\text { Alcohol A.excelsa } \\
\text { extract }\end{array}$ & 250 & 4 & $3.0 \pm 2.28$ & 66.66 \\
\hline
\end{tabular}

\section{DISCUSSION}

In this research the effects of aqueous and alcohol leaf extract of A.excelsa were studied using histopathological examination of testes and fertility index.

In this Study the affected Seminferous tubules showed separating of the spermatogenic cells from the germinal layer (Fig.2), this due to the germ cells were not produced primary spermatocytes. In addition congestion of blood vessels, this effect was occurred as a result of defection in blood flow to the main veins. The increasing in Leydig cells is leading to increase testosterone, and this hormone excites epithelial tissue of semniferous tubules to products sperms. The results observed occurrence of giant cells which appeared in many histopathological alteration, this is in agreement with Mishra and Singh, (2005).

It can be seen from the results that A.excelsa leaf extract possesses male antifertility agent in mice which was found to be reversible on fertility, (Table 1). The result indicated that male antifertility due to the effect of the extract on the different types of germ cells, perhaps associate with hormonal effect on spermatogenesis. This result is in agreement with Sadre et al., (1983), who reported that A.indica aqueous leaf extract caused antifertility activity in rats. Also Mishra and Singh (2005) observed that A.indica leaf extract caused reversible alternations in the reproductive organs of mice.

In this study, the results showed a decrease in spermatozoa in treated groups compared with control group (Fig. 2, 3), thus the affected sprematogenic cells do not reach their normal maturation, each of these effect on any stage leads to the retardation of spermatogenesis in males. Azadiractin has the ability to act as a powerful spermicidal, Sadre et al., (1983). Kasturi et al., (2002) found that Crude leaf extract of A.indica caused a defects in late spermatids and other effects in spermatogenesis in albino rats through antispermatogenic and antiandrogenic properties.

In the present study, the results showed that mean number of newborns was decreased in females which mated with treated male groups. Fertility index was reduced by the effect 
Waad S. Shaher

of A.excelsa extracts on the number of spermatozoa and its ability to fertilize. Sadre et al., (1983) reported that A.indica leaf extract caused reduction in fertility and decreased the mean number of newborn in rats. Female rats were remained infertile for variable periods ranging from 107 to 180 day after given a single dose $(100 \mu \mathrm{l})$ of neem oil by intrauterine route (Shakti et al., 1990). Shahir (2002) also found the same effects of crushed fruits of Melia azedarach in rats.

In addition, Ailanthus excelsa leaf extract and stem bark at dose $250 \mathrm{mg} / \mathrm{kg}$ b.w. exhibited a remarkable antimplantation and early abortificient activity in female albino rats (Dhanashekaran et al., (1993), Morovati et al., (2008)) reported that A.indica extract Neem Azol-T/s caused increase in mean delay for pregnancy in rats.

From this results A.excelsa extracts could be used as an antifertility agent to control harmful agricultural rodents.

\section{REFERENCES}

Akhtar, Y.; Yeoung, Y.R.; Isman, M.B. (2008). Comparative bioactivity of selected extracts from meliaceae and some commercial botanical insecticides against two noctuid caterpillars, Trichoplusiani and Pseudaletia unipuncta. Phytochemistry Reviews. Vol. 7(1), 77-88.

Bardhan, J.; Rair, S.S.; Sawhney, R.C.; Kain, A.K.; Tomas, P.; Havazhagan, G. (1991). Neem oil: A fertility controlling agen in rhesus monkey. Ind. J. Physiol and Pharmacol., 35, 278-280.

Choochote, W.; Kanjanapothi, D.; Panthong, A.; Taesotikul, T.; Jitpakdi, A.; Chaithong, U.; Pitasawat, B. (1999). Larvicidal adulticidal and repellent effects of Kaempferia galanga., Southeast Asian J. of Trop. Med. and Public Health. Vol. 30, 470-476.

Chungpongse, S. ; Buranatham, W. (1991). "Azadirachta excelsa (Jack) Jacobs". Songkhla Nursery Center, Songkhla, Thailand, pp.10-15.

Dhanashekaran, S.; Suresh, B.; Sethuraman, M.; Rajan, S. (1993). Antifertility activity of Ailanthus excelsa Roxb, in female albino rats. Indian J. of Exper. Biol., 31, 384385.

Doll, M.; Schmutterer, H. (1993). Vergleich der wirkung von samenkernextrakten und ol von Azadirachta excelsa (Jack) (=A. intergrifoliola Merr.) und Azadirachta indica (A. Juss) beim mexikanischen bohenenkafer Epilachna varuvestis (Muls.). Mitt. Dtsch. Ges. Allg. Angew. Entomol. 8: pp.775-780.

Hein, D. (1994). Gegenstromchromatographische reinigung biologisch aktiver tetranortriterpenoide aus samen des neim-(Azadirachta indica A.juss) und marrangobaumes (Azadirachta excelsa Jack) und ihre NMR-spektrometrische charakterisierung. Diploma thesis, Univ. of Giessen.

Joshi, A.R.; Ahamed, R.N.; Pathan, K.M.; Manivannan, B. (1996). Effect of Azadirachta indica leaves on testis and its recovery in albino rats. J. Exp. Biol. 34(11) ,10911094. 
Kasturi, M.; Ahamed, R.N.; Pathan, K.M.; Manivannan, B.; Aladakatti, R.H. (2002). Ultrastructural changes induced by leaves of Azadirachta indica (Neem) in the testis of albino rats. J. Basic Clin. Physiol. Pharmacol., 13(4), 311-328.

Lean, T.N.; Yuen, P.M.; Loke, W.H.; Abdulkadir, A. (2003). Effects of Azadirachta excelsa on feeding behaviour, bodyweight and mortality of Crocidolomia binotalis Zeller (Lepidoptera: Pyralidae). J. of the Sci. of food and Agicul. Vol. 83 Issue 13., 1327-1330.

Macedo, F.R.; Louvandini, H.; Paludo, G.R.; Mc Manus, C. M.; Porto, A.D. (2007). Effects of Ailanthus indica on sheep infected naturally with helminthes. american $J$. of Anim. And Veter. Sci. 2(4), 121-126.

Mishra, R.K.; Singh, S.K. (2005). The effect of aqueous leaf extract of Azadirachta indica on reprductive organ in male mice. Indian J. Exper-Biol. Vol. 43(11), 10931103.

Morovati, M.; Mohamoudi, M.; Ghazi-Khansari, M.; Khalil Aria, N.; Jabbari, L. (2008). Sterility and abortive effects of the commercial neem (Azadirachta indica A. juss) extract neemazal-T/s on female rat (Rattus norvegicus). Turk J. Zool., 32, 155-162.

Mukherjee, S.; Garg, S.; Talwar, G.P. (1999). Early post implantation contraceptive effects of a purified fraction of neem (Azadirachta indica) seed, given orally in rats: possible mechanisms involved. J. Ethnopharmacol. 67, 287-296.

Nor Aini, A.S.; Seong, L.K. (2006). Azdirachtin variation of six provenances of Azadirachta excelsa (Jack) Jacob. Pakistan J. of Biol. Sci. 9(5), 833-836.

Norani, A., (1997). Azadirachta excelsa a monograph. Research pamphlet No. 120. FRIM, 59p.

Randhawa, N.S.; Parmar, B.S. (1993)." Neem Research and Development". Society of pesticide science. India New Delhi Agricul. Res. Inst., 283p.

Sadre, N.L.; Deshpande, V.Y.; Mendulkar, K.N.; Nandal, D.H. (1983)." Male Antifertility Activity of Azadirachta indica in Different Species". Rauischholzhausen., pp.473-482.

Schumutterer, H.; Doll, M. (1993). The marrango on philippine neem tree, Azadirachta excelsa (=A. intergrifoliola): A new source of insecticides with growthregulating properties. Phytoparasitica. 21, 79-86.

Shahir, W.S. (2002). Effects of chinaberry tree Melia azedarach L. on some tissues and fertility in rats (Rattus norvegicus) . Ph.D. Thesis. College of Science, University of Mosul.

Shakti, N.; Upadhyay, C.K.; Talwar, G.P. (1990). Anftifertility effects of neem (Azadirachta indica) oil by single intrauterine administration: anovel method for contraception. Biol. Sci. 242(1305), 175-179. 